\title{
Diagnostic difficulties by the unusual presentations in children and adolescents with Hashimoto thyroiditis
}

Betül Ersoy, MD',

Seniha Kiremitch Yilmaz, MD', Deniz Kızılay, MD', Münevver Yılmaz, MD², Şenol Coşkun, MD²

'Division of Pediatric Endocrinology, Department of Pediatrics, School of Medicine, Celal Bayar University, Manisa, ${ }^{2}$ Division of Pediatric Cardiology, Department of Pediatrics, School of Medicine, Celal Bayar University, Manisa, Turkey https://doi.org/10.6065/apem.2016.21.3.164

Ann Pediatr Endocrinol Metab 2016 Sep;21(3):164-168.

In this paper, the second author's name was misprinted unintentionally. The full name and brief name should be corrected as follows:

Corrected the second author's name

Full name: Seniha Kiremitch Yilmaz

Brief name: Kiremitch Yilmaz S 